\title{
An Analysis of the Determinants of Banks Performance in Case of Private Commercial Banks in Ethiopia
}

\author{
Zelalem Borena Bono \\ Lecturer of Accounting and Finance, College of Business and Economics, Wolaita Sodo University
}

\begin{abstract}
The purpose of this study is to investigate determinants of private commercial banks profitability in Ethiopia by using panel data of three private commercial banks from year 2007 to 2016 . The study used quantitative research approach and secondary financial data are analyzed by using multiple linear regressions models for the two bank profitability measures; Return on Asset (ROA) and Return on Equity (ROE). Fixed effect regression model was applied to investigate the impact of capital adequacy, deposit mobilization, interest rate, liquidly, bank size, and real GDP growth rate on major bank profitability measures i.e., (ROA), (ROE), separately. The empirical results shows that bank specific factors; capital adequacy, interest rate, bank size and macro-economic factors; level of GDP, and regulation have a strong influence on the profitability of private commercial banks in Ethiopia. Thus, management bodies of private commercial bank should strive to strengthen the identified significant factors and government bodies should also see the adverse effect of tight polices imposed on the existing private banks as well as for the new entrants.
\end{abstract}

Keywords: Profitability, ROA, ROE, Commercial Banks

DOI: $10.7176 / \mathrm{EJBM} / 11-31-06$

Publication date: November $30^{\text {th }} 2019$

\section{Introduction}

Banks are financial institutions which target mainly profit by expanding different earning capacities and minimizing expenses, as it is the ultimate objective of any firms. Commercial banks are one of the banking sectors which are the main source of funding to business activities as well as other projects throughout the country. They play a key role in the economy by mobilizing deposits from surplus units to deficit units in the form of loan and advances (Daniel and Wandera, 2013). There are so many types of worldwide money transfers which are directed by the different licensed agents like western union, money gram, golden money transfer, and etc, channeled through banks that help to the bank retaining commission, thereby expanding the amount of profit. Ethiopian banking industry is progressing drastically recently all over the country since the past two decades. This increment is both in the number of banks and also branch expansion within a given bank. Due to this the researcher emphasizes the study on the three privately owned commercial banks; Unitd bank, Dashen bank and Nib international bank intentionally these selected because of the fact that older in banks which helps to gather adequate data for the study.

\subsection{Statement of the Problem}

All banks in the world, whether they are public or privately owned are established aiming to have remarkable return to satisfy their shareholders, besides satisfying their customers by rendering moderate services and employees by rendering a better earning. To be profitable a given bank must have competitive advantages like equipping with advanced technology and network interconnection between branches and within banks to manage its deposit mobilization, revenue from loans and advances, commissions from different sources and, in general increasing deposit and earnings and decreasing expenditures or expenses. Due to internal and external factors most banks fail to attain their expected profit with in a given period of time. Due to the time gap between what the previous researchers' observations and opinions on these observations will fill the research gap like not focusing specially on deposit mobilization, since it is the backbone of banks good performance, will be the expected findings on this study. Such types of observations under selected banks initiate investigator to make the study and expected to clear detection of the problem and then the unique solution after the completion of this thesis.

\subsection{Objectives of the Study}

The general objective of the study is to asses determinants of profitability under privately owned commercial banks. The study focuses on the following specific objectives

* To evaluate the effect of deposit mobilization on profitability of the selected private commercial banks.

* To identify the firms' Interest income determination on the profits of private commercial banks.

* To find out the relationship between the profitability and firms capital adequacy on profitability of selected private banks.

* To identify the effect of bank size on profitability of selected private commercial banks.

* To show the size of liquidity on profitability of selected banks. 


\subsection{Hypothesis}

Based on the existing theoretical and empirical literatures, this study will explore the extent of growth of profitability can be explained by those variables.

H1: Deposit mobilization has statistically significant positive/negative impact on profitability of banks.

H2: Interest income has statistically significant positive impact on profitability of private banks.

H3: Liquidity has statistically significant positive/negative impact on profitability of banks.

H4: Capital adequacy has statistically significant positive/negative impact on profitability of bank.

H5: Bank size has positive/negative impact on profitability of banks

\subsection{Scope of the Study}

The scope of the study is factors affecting the determinants of profitability under privately owned commercial banks. The data will be collected from the three privately owned banks namely Dashen bank, Nib international bank and United bank financial statements of periods covering from the year ended 2007 G.C to 2016 G.C.

\section{Literature Review}

The term profitability consists of two words, profit and ability, Kaguri (2013). It is necessary to differentiate between the words profit and profitability at this point. Profit, from accounting point of view, is arrived at by deducting from total revenue of an enterprise all amount expended in earning the income, while the term profitability is defined as the ability of management of a given investment to earn a return from its use. The reason for continued existence of every business organization and its expected so as to meet the required return by owners and other outsiders. According to Kabajah and et al (2012), there are different ways to measure profitability, such as: Return on asset (ROA) ratio, return on owner's equity (ROE) ratio and return on investment (ROI). ROA ratio is measured by as net profit after tax divided by total assets. This ratio measures for the operating efficiency for the company based on the firm's generated profits from its total assets. Most researchers in the field of bank and its profitability stated that the key indicator of a firm's profitability is ROA defined as the before tax profits divided by total assets. Hardwick and Adams (1999) and Malik (2011) are among others, who have suggested that although there are different ways of measuring profitability, it is better to use ROA.

Profit is a return on investment to any business organizations unlike not for profit organizations(NGO's). The study of profits of banks is important not only because of the information it provides about the health of the bank in any given year, but also because profits are a key determinant of growth and employment in a given country. Changes in profitability are an important contributor to economic progress via the influence profits have on the investment and savings decisions of companies. This is because a rise in profits improves the cash flow position of companies and offers greater flexibility in the source of finance for corporate investment i.e. through retained earnings. Easier access to finance facilitates greater investment which boosts productivity, productivity capacity, competitiveness, and employment.

\section{Research Methodology}

\subsection{Research Design}

The main objective of this study was to investigate the determinants of private commercial banks profitability in Ethiopia and this study adopted an explanatory approach by using balanced panel research design to realize a stated objective. As quoted from Tobias and Themba (2011) the advantage of using panel data is that it controls for individual heterogeneity, less collinearity variables and tracks trends in the data something which simple timeseries and cross-sectional data cannot provide (Baltagi 2005). The study was employed quantitative research approaches by using secondary data gathered from financial statement of private commercial banks. For secondary data analysis the study was used E-views 8 software.

\subsection{Sample Design \& Sampling Techniques}

It is very difficult or sometimes even impossible involving all the population in the study of certain interests, that is eager to know about in a given research or study due to limitation in time, budget and so on. Due to this among the whole private banks mentioned above in the population, the three banks which are, Dashen bank, Nib international bank and United banks are selected as of their elder in age and other privilege conditions like their using modern technology which helps having enough information to the study and my being a staff at these three banks different times which helps access the sources by easily communicating the concerned staffs members for gathering information.

The study was based on the panel of selected private banks' data with non-probability judgment sampling design. It was taken maximum of $\mathrm{N}$ cross sectional units or observations and a maximum of $\mathrm{T}$ time periods. This means each cross-sectional unit was the same number of time series observations. 


\subsection{Source and Type of Data}

The data for different variables in this study was obtained from Balance sheets and profits and losses of selected banks for the period 2007-2016 G.C. Because of the short history of private commercial banks it is impossible to find data for all private commercial banks operated in Ethiopia. And then we obliged to select a few banks based on their years of establishment. Accordingly data for this paper was from, Dashen bank, Nib international bank and united bank on their annual audited financial reports of balance sheet and income statements of successive years.

\subsection{Data analysis}

The collected data was analyzed by using descriptive statistics, correlations, and multiple linear regression analysis 3.4.1. Descriptive statistics

Mean, minimum, maximum and standard deviation values are used to analyze the general trends of the data from 2007 to 2016 for the variables which included in the study. A correlation matrix was used to examine the relationship between the dependent variable and explanatory variables to investigate multicolinarity problem between variables.

\subsubsection{Method of Data Analysis}

Here, in this study both descriptive and panel econometrics method of data analysis has been employed to discover the effects of bank specific and macroeconomic factors on the profitability of Ethiopian private commercial banks. Descriptive data analysis has been used to describe the profitability trend of commercial banks that has been used under the study and to show summary statistics for variables used under the model. For the econometrics part, random effect panel data analysis has been used.

\subsection{Model Specification}

The model for this study used variables that have significant effect on the profitability of commercial banks as researched by different scholars for different countries to see whether or not the study holds true for Ethiopian private commercial banks. Far from previous researchers the present study includes additional variables as determinant factor for the profitability of banks such as; foreign exchange, deposit mobilization, interest rate, liquidity and bank size. A multiple linear regression model was used to determine the relative importance of each independent variable to determine banks profitability. The p-value of explanatory variables was used to test the hypotheses at a $1 \%, 5 \%$ and $10 \%$ significance level. The multiple linear regressions model for ROA and ROE is shown on equations below. These models were run by using E-views 8 software. The Three private commercial banks financial statement was used to analyze the profitability of private banks in Ethiopia. The adopted regression models are presented as follows;

ROAit $=C i+\alpha 1 I N T i t+\alpha 2$ DEP $i t+\alpha 3 B S i t+\alpha 4 L I Q+\alpha 5 \mathrm{CAPit}+\beta 6 R G D t+e i---------(1)$

ROEit $=C i+\alpha 1 I N T i t+\alpha 2 \mathrm{DEP} i t+\alpha 3$ BSit $+\alpha 4 L I Q+\alpha 5 \mathrm{CAP} i t+\beta 6 R G D t+e i----------(2)$

Where;

ROAit $=$ return on asset of bank $i$ at time $t$

ROEit $=$ return on equity of bank $i$ at time $t$

INT it $=$ interest rate of bank $i$ at time $t$

DEPit $=$ Deposit mobilization $i$ at time $t$

CAPit $=$ Capital adequacy of bank $i$ at time $t$

LIQit $=$ Liquidity of bank $i$ at time $t$

$\mathrm{BSit}=$ size of the bank $i$ at time $t$

$\mathrm{RGDt}=$ Real GDP growth rate at time $t$

Where $t=2007-2016, C i=$ constant for each bank (fixed effects), $\alpha=$ bank specific factors coefficients, $\beta=$ macroeconomic factor coefficients.

\section{Result and Discussion}

\subsection{Descriptive statistics of variables}

In this section descriptive statistics for the dependent; Return on Asset (ROA) and Return on Equity (ROE) and explanatory variables involved in the regression model are presented. Mean, maximum, minimum and standard deviation values are included in the table below. These figures are gives overall description about data used in the regression models. The table below shows descriptive statistics for all variables. Return on Asset and Return on Equity all are a positive mean value 2.39 and 21.31 respectively. There is greater variation in the data set of Return on Equity, because some banks are employed more capital, which increases banks ROE. Bank size, liquidity and GDP show high mean value of $9.15,47.43$, and 9.26 respectively. Liquidity which measured by total loan to total deposits has been a highest mean Value, that means there is no liquidity problem because, the data shows their level of total deposits greater than the total loans. 
Table 4.1 Descriptive statistics of variables

\begin{tabular}{lllll}
\hline Dependent variables & Mean & Max & Min & Std. Dev \\
& & & & \\
\hline ROA & 2.39 & 4.68 & -2.37 & 1.42 \\
ROE & 21.31 & 42.29 & -3.58 & 11.31 \\
& & & & \\
\hline Independent Variables & Mean & Max & Min & Std. Dev \\
& & & & \\
\hline Capital adequacy & 0.60 & 10.15 & 0.06 & 1.77 \\
Deposit mobilization & 5.89 & 14.75 & 0.00 & 2.74 \\
Interest rate & 0.48 & 1.93 & -0.01 & 0.35 \\
Liquidity & 47.43 & 128.57 & 20.34 & 18.98 \\
Bank size & 9.15 & 10.17 & 4.86 & 1.06 \\
GDP & 9.26 & 12.70 & -2.10 & 4.70 \\
\hline
\end{tabular}

Source: E-views8 output from private banks financial statements

It can be seen from the above table, Return on asset has mean value of 2.39 , which is lowest as compared to that of other dependent variables. The standard deviation 1.42 and range 7.15 showed that there was lowest variability in the data for the profitability measures. Return on equity has average value of 21.31 it is the highest of all dependent variables. The standard deviation 11.31 and range of 45.87 showed high variability. Capital adequacy has the second lowest mean value of 0.60 ; the range was 10.21 which show moderate variability, and the moderate standard deviation of 1.17 as compared to other independent variables. This shows that the data was consistent because the standard deviation value is not much far from the mean value. The capital adequacy mean value results suggest that about $60 \%$ of the total assets of private commercial banks were financed by shareholders funds while the remaining $40 \%$ was financed by deposit liabilities.

Deposit mobilization has the average value of 5.89 and the standard deviation value of 2.74 . The minimum and maximum value is 14.75 , and 0.00 respectively. Interest rate has the moderate mean value of 0.48 , and the range of 1.94 which shows the lowest variability, the standard deviation value of 0.35 which is the lowest variability as compared to other explanatory variables. The mean value of liquidity of private banks was 47.43 , and the range of 148.91 which is the highest variability among variables. The standard deviation value of the variable is 18.98 , highest deviation as compare to other explanatory variables. The bank size plays an important role to maintain the position of a bank in the market. The size of private commercial banks under this study has mean value of 9.15 , and the maximum and minimum value of 10.17 and 4.86 respectively. But the standard deviation value is 1.06 which the third highest value among independent variables. These results show that private commercial banks in Ethiopia have a small variation in their total asset. The last independent variable is the level real GDP growth rate, has the highest standard deviation value of 4.07, and the mean value of 9.26. The maximum and minimum value is 12.07 and -2.10 respectively. According to the above table, from the independent variables liquidity and GDP growth rate have large standard deviation of 18.98 and 4.70 respectively compared with other variables. It revealed that the liquidity in the bank and level of GDP growth rate have more significant variance than other explanatory variables included in the study.

\subsection{Regression analysis between return on asset and explanatory variables}

To examine the relationship between profitability measures and explanatory variables two regression analysis were run. The first regression analysis was undertaken to investigate the relationship between ROA and independent variables. This regression model was applied:

$\mathrm{ROA}=-9.92+0.14 \mathrm{CAP}+0.24 \mathrm{DEP}+0.77 \mathrm{INT}-0.005 \mathrm{LIQ}+1.1 \mathrm{BS}+0.08 \mathrm{RGDP}$

In the following table coefficients, standard errors, $\mathrm{t}$-values, and $\mathrm{p}$-values for explanatory variables, and $\mathrm{R}$ squared, Adjusted R-squared, Standard Error of regression, F-statistic, Prob (F-statistic) for the regression, and number of observations included in the study are presented. 
Table 4.2 Regression analysis result between ROA and explanatory variables

\begin{tabular}{lllll}
\hline & Coefficient & Standard error & t-value & p-value \\
\hline C & -9.927832 & 3.657338 & -2.714496 & 0.0089 \\
Capital adequacy & 0.147898 & 0.067563 & 2.189025 & $0.033^{* *}$ \\
Deposit mobilization & 0.245768 & 0.613518 & 0.400588 & 0.690 \\
Interest rate & 0.775045 & 0.145777 & 5.316634 & $0.000^{* * *}$ \\
Liquidity & -0.005320 & 0.004070 & -1.307147 & 0.197 \\
Bank size & 1.178303 & 0.223084 & 5.281883 & $0.000^{* * *}$ \\
GDP & 0.089835 & 0.015638 & 5.744680 & $0.000^{* * *}$ \\
& & & & \\
\hline
\end{tabular}

\begin{tabular}{ll}
\hline R-squared & 0.72349 \\
Adjusted R-squared & 0.690427 \\
S.E of regression & 0.510739 \\
F-statistic & 37.38744 \\
Prob(F-statistic) & $0.0000^{* * *}$
\end{tabular}

$* * *$ Significant at $1 \%$;

** Significant at 5\%;

*Significant at $10 \%$

Source: E-views output from private banks financial statements

As it can be seen from the above table, interest rate, bank size and level GDP growth rate are statistically significant at 1 percent significant level, capital adequacy was statistically significant at 5 percent with return on asset. All explanatory variables have a positive relationship with return on asset in agreement with the hypothesis except liquidity, low coefficient of -0.005 shows that liquidity has weak impact on the profitability of private commercial banks and any increase in liquidity leads to poor profitability. A positive coefficient of capital adequacy (0.147) implies that an increase in capital leads to increase profitability. The interest rate has a positive coefficient of 0.77 ; this means operational cost efficiency leads to better profitability. Similarly, bank size and GDP have a positive coefficient of 1.178 and 0.089 respectively. This means any increase in these variables leads to increase in profitability of private banks in Ethiopia.

$\mathrm{R}$-squared is measured the goodness of fit of the explanatory variables in explaining the variations in banks profitability measure ROA. As clearly described in Table 4.9 R-squared value for the regression model was 0.72 . This indicates the explanatory variables in this study jointly explain about 72 percent of the variation in the profitability measure, return on asset. The remaining 28 percent of the variation in the profitability of private banks explained by other variables which are not included the model. Therefore, these explanatory variables together, are good explanatory variables of the profitability of private commercial banks in Ethiopia. Beside this F-statistics (37.39) which is the used to measure the overall test of significance of the model was presented, and null hypothesis can be clearly rejected since the p-value is 0.0000 which is sufficiently low, the model is well fitted at 1 percent level of significance.

\subsection{Regression analysis between return on equity and explanatory variables}

The second regression analysis was done to know how much the bank is earning on their equity investment, an amount that is measured by the return on equity (ROE) in relation with explanatory variables included in this study. This regression model was used:

$\mathrm{ROE}=-2.17+0.26 \mathrm{CAP}-1.92 \mathrm{DEP}+4.34 \mathrm{INT}-0.09 \mathrm{LIQ}+4.85 \mathrm{BS}+1.05 \mathrm{GDP}----------(2)$ 
Table 4.10 Regression analysis result between ROE and explanatory variables

\begin{tabular}{lllll}
\hline & Coefficient & Standard error & t-value & p-value \\
\hline C & & & -1.867862 & 0.067 \\
Capital adequacy & -2.17298 & 3.28564 & 0.408655 & 0.684 \\
Deposit mobilization & 0.259346 & 0.634633 & -0.332551 & 0.741 \\
Interest rate & -1.916444 & 5.762856 & 3.171534 & $0.000^{* * *}$ \\
Liquidity & 4.342801 & 1.369306 & -2.275245 & $0.027^{* *}$ \\
Bank size & -0.086980 & 0.038229 & 2.316434 & $0.024^{* *}$ \\
GDP & 4.853988 & 2.095457 & 7.178447 & $0.000^{* * *}$ \\
& 1.054440 & 0.146890 & & \\
\hline R-squared & & & & \\
Adjusted R-squared & 0.703361 & & & \\
S.E of regression & 0.660159 & & & \\
F-statistic & 4.797441 & & & \\
Prob(F-statistic) & 25.70260 & & & \\
& $0.000000 * * *$ & & & \\
\hline$* *$ Significant at $1 \% ;$ & & & & \\
\end{tabular}

$* * *$ Significant at $1 \%$;

$* *$ Significant at $5 \%$;

*Significant at $10 \%$

Source: E-views output from private banks financial statements

In the above table coefficient, standard error, $t$-value, and p-value for all explanatory variables and the value of R-squared, adjusted R-squared, S.E of regression, F-statistics with p-value and number of observations included in this study were presented.

As per table 4.10 above, managerial efficiency and level of GDP has a positive relationship with profitability measure; return on equity, and both are statistically significant at 1 percent significance level. According to the above table, against to the hypothesis stated the regression analysis result indicated that deposit mobilization and liquidity have a negative relationship with the bank profitability measure; return on equity. Although, there is negative relationship between return on equity and liquidity, it is significant at 5 percent significance level, which means the more liquidity the bank, the lower the profitability.

Table 4.10 also shows that variations in the dependent variable for the profitability, as measured by return on equity, are explained satisfactorily by variations in the selected explanatory variables, Because R-squared 0.70 , which indicates that explanatory variables included in the study together explain about 70 percent of the variation in the profitability. The remaining 30 percent variation in the profitability of private commercial banks in Ethiopia is explained by other variables which are not included in the study. Table 4.7 also presented, the value F-statistics is 25.70 with p-value of 0.0000 , which used to measure the overall significance of the regression model. The null hypothesis can be clearly rejected since the p-value is 0.0000 which is sufficiently low and we can say that the model is well fitted at 1 percent level of significance.

\section{Conclusion and Recommendation}

\subsection{Conclusions}

Descriptive analysis results revealed that almost all private commercial banks are applying relatively consistent interest rate on all kinds of finances and there is only few variations was observed in net interest margin. The capital adequacy mean value results suggest that about $60 \%$ of the total assets of private commercial banks were financed by shareholders funds while the remaining $40 \%$ was financed by deposit liabilities. The mean value of liquidity shows that the Ethiopian private commercial banks was very liquid, two times more than the minimum statutory liquidity ratio of 20 percent set by National Bank of Ethiopia (NBE). In relation to ROA, interest rate, bank size and level GDP growth rate have significant impact on the profitability of private banks. All explanatory variables have a positive relationship with return on asset in agreement with the hypothesis except liquidity, low coefficient shows that liquidity has weak relationship with profitability. Asset quality and liquidity level of private commercial banks included in this study has no significant relationship with ROA. The explanatory variables included in this study jointly explain about 72 percent of the variation in return on asset.

With regard to ROE as a profitability measure for the study, interest rate and level of GDP has a positive relationship and significant at 1 percent significance level. Liquidity and the size of bank are also statistically significant with return on equity at 5 percent significance level. Against to the hypothesis the regression analysis result indicated that asset quality and liquidity have a negative relationship with return on equity. Although, there is negative relationship between return on equity and liquidity, it is significant, which means the more liquidity the bank, the lower the profitability.

Based on the findings it can be concluded that interest rate, bank size, level of GDP, and capital adequacy 
have significant impact on ROA; which means any increase (decrease) on the value of these variables leads to an increase (decrease) on profitability of private commercial banks in Ethiopia. Interest rate, liquidity, bank size and GDP have significant influence on ROE and except with the liquidity all these variables have positive relationship with profitability of private banks.

\subsection{Recommendations}

Management bodies of private commercial banks should strive to strengthen the bank specific factors like capital position, deposit mobilization, interest rate and bank size. Because, The competition become tough since increase in new entrant to the market, banks are increasingly being substituted by the general public as a source of funds by new share companies being established in a variety of sectors, and the micro-finance industry continues to show rapid growth. Tight government regulations towards the banking sector were one of the major determinants factors for the profitability of private commercial banks. Accordingly, government bodies should see the adverse effect of the policies imposed on the banks for existing private banks as well for the new entrants. For instance, new directive of NBE towards capital reserve requirement, liquidity position of banks reduced the deposit growth rates from 30-35 to 20-25 percent per year as stated in access capital research (2011), and tight credit policies may create or worsen an existing inflationary situation and make realistic interest rate levels difficult to achieve.

In general, as many literatures supports financial intermediation in Ethiopia is still in its early stages even by the standards of other low-income countries: more than 90 percent of the population is unbanked (versus an average of 60-70 percent elsewhere in Africa); and many other metrics such as the total number of banks, banks contribution to GDP, bank accounts per person, branches per person, and bank credit per person are lower in Ethiopia compared to other African countries. Thus, private commercial banks should focus to reach this unmet demand of finance by adjusting their strategy with the government regulation.

At last, this study investigates the determinants of profitability of private commercial banks in Ethiopia. But, the variables included in the study were not exhaustive. Future researchers could include other bank specific and macroeconomic variables such as inflation and exchange rates in the regression models.

\section{Bibliography}

Aburime, U.T. el (2007). Determinants of bank profitability:Company- level evidence from Nigeria,Afrrican journal of accounting,Economies,Finance and banking research, 2, 58-82

Anna P. I. Vong and Hoi Si Chan (2008). Determinants of bank profitability in Macao, Faculty of business administration, university of Macao.

Banwo S. (1997). The Funds flow Statement: Towards Enhanced Utility. 1997 ICAN News, July/September, pp $23-29$.

Berger A. (1995). The relationship between capital and earnings in banking. Journal of money, credit and banking. , Vol.27, 404-431.

Ben Naceur, S. OmranM.(2008). The effects on bank regulation,competiation and finantial reforms on MENA banks profitability.Working paper, Economic research Forum.

Chan, H. and Vong A.(2010). Determinants of profitability in Macao, University of Macau.

Demirgue Kunt A.and Huizinga H.(1999). Determinants of commercial bank interest marigins and profitability:some international evidenc. In World bank economic review,13 (pp. 379-408).

Flamini,V.,McDonald,C.\& Schumascher,L. (2009). Determinants of profitability in sub-seharan Africa.IMF Working paper NO 09/15,pp.1-30.

Kabajah, AL Nu'aimat and Dahmath, 2012, 'The relationship between ROA, ROE, and ROI relations with Jordanian insurance public Companies Market share prices', International Journal of Humanities and Social Science, Vol, 2, no. 11,pp. 115-120. 